\title{
Researcher refuses to back down over race case
}

Up on the seventh floor of Building 16 at the Massachusetts Institute of Technology (MIT) in Cambridge, biological engineer James Sherley already has his schedule for 1 July mapped out. "I plan on coming into my office, just like I normally do," he says. "They'll have to come in here and drag me out."

Time is running out for the stem-cell researcher - a year and a half, one hunger strike and countless e-mails after being denied tenure. MIT has told him that 30 June is his last day. But Sherley has no intention of going quietly.

Sherley, who is African-American, has argued that racial discrimination and colleagues' conflicts of interest marred his tenure process. Under-represented minorities (African-American, Hispanic and Native American) make up only $3.6 \%$ of the senior faculty at MIT; the US national average is 3.5\% in natural science and engineering at élite research universities.

"I am just tired of racism," says Sherley. "Here I am again at a point where I am being denied something that I deserve because of my race."

Frank Douglas, who is African-American, also resigned in protest as executive director of MIT's Center for Biomedical Innovation this month: "I leave because I would [not] be able to advise young Blacks about their prospects of flourishing in the current environment."

Sherley says signs of discrimination were evident from the moment he arrived at MIT, eight years ago. Requests to expand his lab space were denied, he says, and his lab was rarely invited to speak at departmental seminars.
In March, faculty members at the biological engineering department expanded on their decision not to grant Sherley tenure, saying the process was "as free as humanly possible from bias and racism". "External letters from experts in the field of stem-cell biology were not strong enough," they wrote. They point out that twothirds of the $\$ 1.5$ million in external funds used to fund Sherley's pre-tenure research came from grants on which Sherley was not the primary investigator. On average, only a third of MIT assistant professors receive tenure.

During the years before the decision, Sherley published six peer-reviewed research papers. Of the two other candidates in his department who were awarded tenure around the time when Sherley's case was being considered, one had published 12 papers during the same period, the other 18. Both bodies of work

\section{"I am being denied} something that I deserve because of my race." other 18 . Both bodies of work
were cited on average twice as often as Sherley's. However, the value of Sherley's research cannot be appreciated merely by counting citations, says George Church, a Harvard University biologist. "It takes a little digging to see it," he says. "They don't give him any credit for the creativity."

Sherley has tackled several open questions in stem-cell biology. He re-evaluated the 'immortal strand' hypothesis proposed more than 30 years ago as a mechanism by which adult stem cells prevent the accumulation of mutations in their DNA. In 2006, after his tenure application was denied, Sherley was awarded the National Institutes of Health Director's Pioneer Award for challenging research directions.

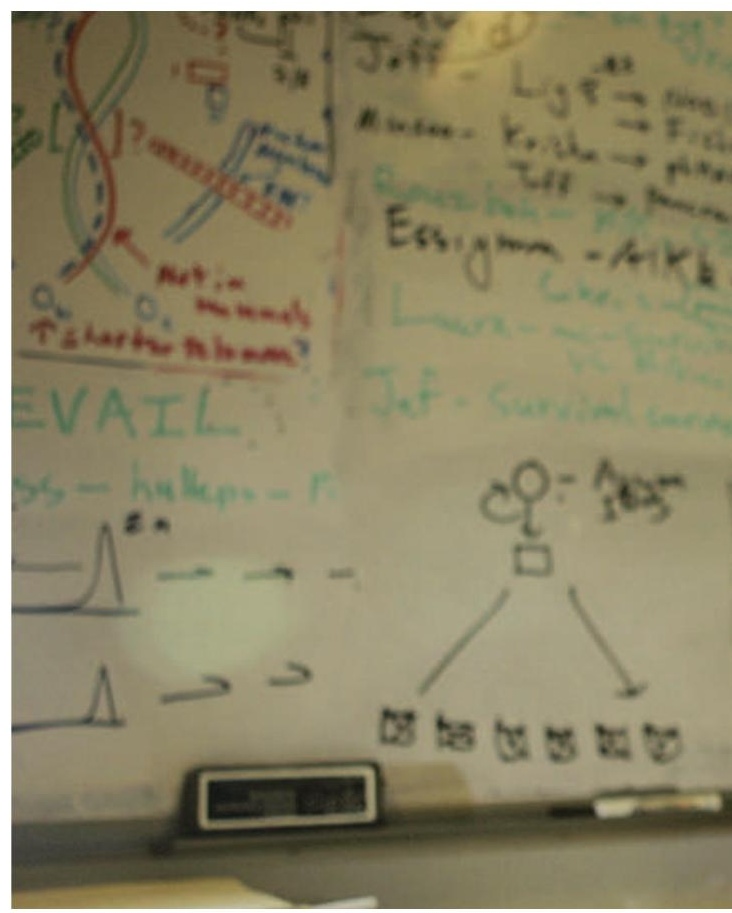

Not everyone feels Sherley's work warrants tenure. "I thought the decision not to grant tenure was correct," says Nancy Hopkins, an MIT biologist who led the institute's evaluation of gender equality in the late 1990s. "I did not detect bias that affected this outcome. However, unintentional racial bias, like gender bias, is unavoidable in our society."

Some speculate that Sherley's controversial opposition to embryonic stem-cell research was a factor. Sherley, who studies adult stem cells, has been critical of embryonic stem-cell research on ethical and practical grounds.

Sherley ended his March hunger strike after 12 days, when, according to him, MIT agreed to re-evaluate his case. MIT says no such agreement was ever made and no further investigation is needed. Sherley says that MIT has failed to hold up its end of the bargain; the university says that the inquiry held before the strike by

\section{Plans falter over EU research infrastructure}

\section{MUNICH}

Europe has a plan for building

large research facilities for scientists to share. Now all it needs to do is figure out which ones may actually become reality - not an easy task. Last week, a high-level meeting in Hamburg ended without concrete suggestions for which projects to take forward.
The list of facilities that European scientists would like funded is long and diverse, from biobank projects to particle accelerators. Some, such as the $€ 360$-million (US\$480-million) research icebreaker Aurora Borealis and the $€ 1$-billion European X-ray Free Electron Laser (XFEL), have already won full or partial approval.
But many others, including a planned $€ 150$-million Extreme Light Infrastructure laser initiative and the $€ 1$-billion European Spallation Source (ESS) for neutron research, are still but dreams.

Thirty-five projects have been identified as key by the European Strategy Forum on Research Infrastructures
(ESFRI). But paying for them all would cost more than $€ 14$ billion. "We all know that it won't be possible to have them all," says Beatrix VierkornRudolph, who is on the ESFRI executive board and an official at the German research ministry.

Governments of the 27 member states, together with the ESFRI and national 


\section{Stem-cell paper corrected}

The authors of a controversial paper on stem cells publish a correction of their work in this week's issue of Nature (see page 880 ), but say their overall conclusions still stand.

The paper in question, published in

2002, claimed to find evidence for so-called 'multipotent adult progenitor cells', or MAPCs, in mouse bone marrow ( $Y$. Jiang et al. Nature 418, 41-49; 2002). The work was led by

Catherine Verfaillie, now director of the Stem Cell Institute at the Catholic University of Leuven, in Belgium.

The correction states that figures showing proteins on the surface of the MAPCs contained many errors, including duplications. Verfaillie's group provides replacement data and says that the correction does not undermine the paper's conclusion that MAPCs can give rise to a wide range of different cell types.

The paper challenged the prevailing idea that only stem cells derived from embryos were highly flexible. Some of its results have been reproduced by other labs, but no one has been able to replicate the work independently in its entirety.

"I believe that despite the hype over the mistake, we and Nature made the conclusion that the final findings of the paper still stand," says Verfaillie.

This February, an investigation convened by the University of Minnesota - Verfaillie's former institution - found that her group had used incorrect procedures in the Nature paper, and that some of the data contained in it might be flawed. The investigation was a response to questions from a reporter from the magazine New Scientist, who pointed out that the figure corrected today was partly reproduced with different labels in another paper in the journal Experimental Hematology (Y. Jiang et al. Exp. Hematol. 30, 896-904; 2002).

In response to the investigation, Nature convened a peer-review panel to analyse the data from the 2002 paper. According to Nature, the experts concluded that although the figure data were flawed, the paper's conclusions are still valid.

No allegations of fraud or misconduct have been levelled at Verfaillie or anyone from her group. There are still two investigations ongoing - one at the University of Minnesota and one at the Catholic University of Leuven - into a second set of allegations raised by New Scientist. These concern data from a paper in the journal Blood (M. Reyes et al. Blood 98, 2615-2625; 2001) and data in a US patent filing.

Verfaillie says her group cannot explain how the errors in the Nature paper occurred: "Why this happened, we have not been able to determine," she says.

Erika Check

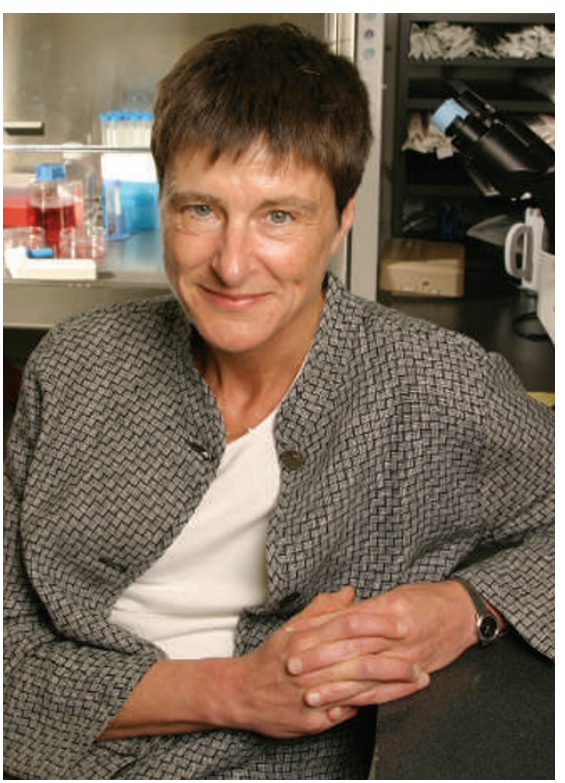

Catherine Verfaillie defends her team's work. funding agencies, now must winnow out those projects to be built from those to be abandoned. This October, they will announce which projects on the list will receive initial funding for technical design studies; an updated roadmap is to be produced by autumn 2008. Projects that are chosen for funding will require one country to take the lead, as Germany has done for the XFEL and the icebreaker.
But even that can be tricky, as negotiating the details of multinational EU projects is a notoriously cumbersome process. Building the XFEL, for example, required separate bilateral agreements between Germany and all the 12 other participating countries. And although Germany had said early on that it would cover $60 \%$ of the building costs and $75 \%$ of the operational costs, it took almost four years to finalize agreements with all partners. The money must come from some extra pot, as the EU's seventh Framework programme for research, which runs from 2007 to 2013, has only an embryonic budget for infrastructures - just enough to fund design studies and facilitate access to existing machines.

Peter Tindemans, who chairs the ESS initiative, suggests that a fraction of the EU's overall budget surplus, some
$€ 3$ billion to $€ 4$ billion each year, should be put aside for funding research facilities. That's twice the current EU spending on infrastructures, and roughly equal to US spending.

"The ministers say research infrastructures are an area where Europe needs to act as a union," says Tindemans. "Let's remind them of their promise to put their money where their mouth is."

Quirin Schiermeier 